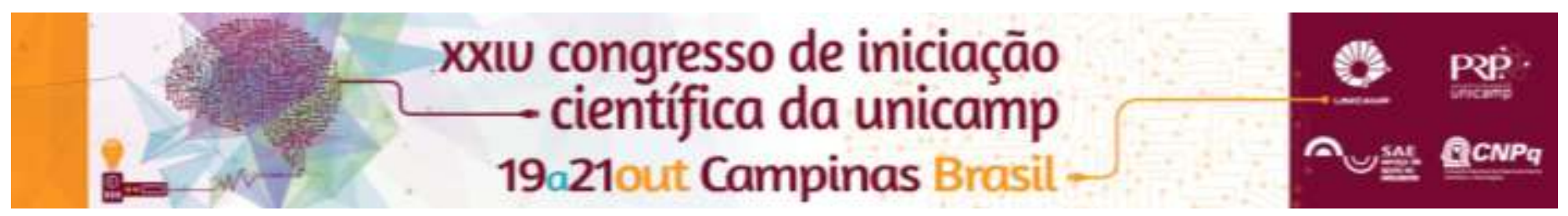

\title{
Incidência de homicídios masculinos na Região Metropolitana de São Paulo nos últimos $\mathbf{3 0}$ anos.
}

\section{Larissa Ghermandi de Almeida*, Ricardo Cordeiro}

\section{Resumo}

Essa pesquisa visa analisar a incidência de homicídios masculinos na Região Metropolitana de São Paulo nos últimos 30 anos através da construção de gráficios tridimensionais, gerados a partir do número e incidência de óbitos por faixa etária a cada ano , e discutir o comportamento desses gráficos, propiciando uma visão macroscópica da situação.

\section{Palavras-chave: \\ Incidência de homicídios, masculinos, Região Metropolitana de São Paulo}

\section{Introdução}

Os homícidios constituem grave problema social no Brasil e, mais especificamente, na Região Metropolitana de São Paulo e afetam desigualmente as camadas da população. Em 1998, eram a principal causa de morte masculina no Brasil, enquanto, para o público feminino, constituíam a $12^{\mathrm{a}}$ principal causa. (Marcos DJ. Homicídios e desigualdades sociais na cidade de São Paulo). Além da diferença no gênero, a diferença econômica também foi significante: Indivíduos de baixa renda foram mais afetados que as classes mais favorecidas.

No contexto internacional, verificou-se, em 2008, que o Brasil possuía a $15^{\text {a }}$ maior taxa de homicídios, ultrapassando diversos países da América Latina que possuíam desenvolvimento econômico semelhante. (Edinilsa RS et al.Estudo multicêntrico da mortalidade por homicídios em países da América Latina.)

Os homicídios, assim, tem apresentado índices alarmantes em âmbito nacional e no contexto do público masculino, principalmente sendo importante o seu estudo na RMSP.

\section{Resultados e Discussão}

Após coleta dos óbitos masculinos por homicídio por faixa etária, ano a ano, e da obtenção da população por faixa etária através de progressão geométrica dos censos de 2000, 2007 e 2010, foram construídos gráficos tridimensionais para análise macroscópica dos dados.

Pôde-se observar um crescimento significativo na incidência dos homicídios masculinos dos anos 80 até final dos anos $90 \mathrm{com}$ posterior queda abrupta a partir do início dos anos 2000,a qual poderia ser explicada pela efetividade de políticas de segurança ou então pela gesta do próprio crime pelo PCC. E notável que a faixa etária mais afetada pelos homicídios é a dos 14 aos 30 anos, por ser a mais envolvida com o mercado ilegal.

O pico na ocorrência dos óbitos ao final da década de 90 é justificável pela economia que estava profundamente afetada, com altos índices de desemprego na RMSP, o que levou ao aumento da aderência ao mercado informal e ilegal. Além disso, foi por volta dessa época que se iniciou a hegemonia do PCC.

Pode-se notar que, a partir do ano 2001, há uma queda abrupta na incidência dos homicídios masculinos, a qual coincide com a implantação do ideal de igualdade pelo PCC, no qual estabeleceu-se que as mortes entre criminosos apenas deveriam ocorrer mediante julgamento e aprovação deste.

Figura 1. Óbitos por faixa etária . RMSP, Brasil, 19792013.

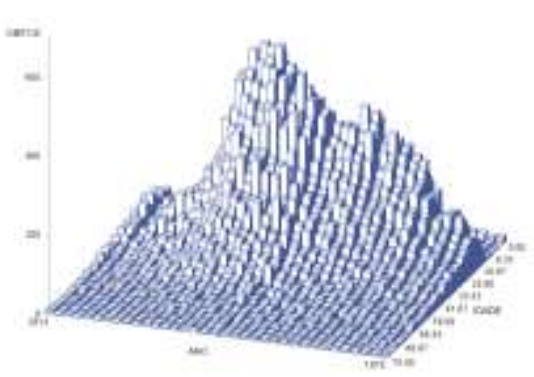

Figura 2. Incidência de óbitos por ano . RMSP, Brasil, 1979-2013.

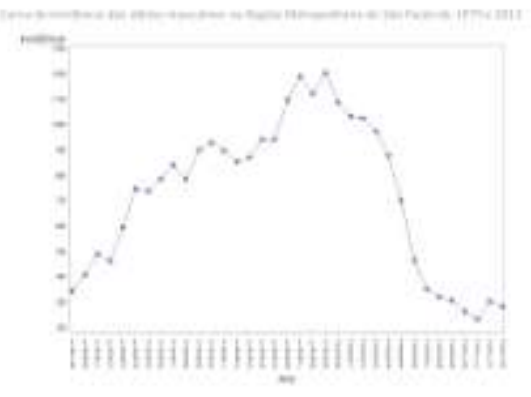

\section{Conclusões}

A redução abrupta no número de óbitos masculinos por homicídios na RMSP deveu-se, mais provavelmente, a políticas de organização do próprio crime e não pela efetividade de políticas de segurança pública.

\section{Agradecimentos}

Agradecemos ao CNPQ pelo financiamento desse projeto e à Fundação SEADE pelos dados.

Feltran, Gabriel de Santis.Governo que produz crime, crime que produz governo:o dispositivo de gestão do homicídio em São Paulo.Rev Brás.de seg.pública.2012. (6): 232-255. 